\title{
Local Wisdom of Lampung Guitar Petting Performed by Saibatin Ethnic
}

\author{
Syahrul Faizin, S.Pd ${ }^{1}$ Dr. A.M. Susilo Pradoko, M.Si Citra Rahma El Kautsar, S.Pd ${ }^{3}$ \\ ${ }^{1}$ Graduate School of Art Education, Yogyakarta State University, Yogyakarta, Indonesia \\ ${ }^{2}$ Graduate School, Yogyakarta State University, Yogyakarta, Indonesia \\ ${ }^{3}$ Graduate School of Performing Art and Visual Art Studies, Gadjah Mada University, Yogyakarta, Indonesia \\ *Corresponding author.Email: syahrulfaizin1@gmail.com
}

\begin{abstract}
Guitar petting is a genre of traditional Lampung music with solo guitar performance used to accompany songs. This guitar play is commonly used in Lampung traditional processions. Overall, this guitar play always goes along with by songs using the Lampung language. This is a qualitative research with an ethnographic approach. The function of the guitar in the Lampung community is as a communication means between a boy and a girl and as an entertainment. Guitar petting is played by strings picked one by one or broken chords played in a rising or descending order. Lampung guitar petting can be played by one person as a guitar player and a singer or can be performed by two people with one guitarist and one vocalist. The coastal tribal guitar petting uses original standard and classical tuning and the Phrygian mode. This guitar petting accompaniment uses improvisation, so that a player can vary in strumming the guitar and on the chords contained in the song. Chords used are the iii, v, and vi chords. Lampung coastal tribe's guitar petting also uses slur technique, and the accompaniment rhythm they make includes slimpat. This rhythm is almost the same as the dangdut pattern but different.
\end{abstract}

Keywords: Local wisdom, play, guitar petting, Lampung coastal tribe

\section{INTRODUCTION}

Ethnic music in Indonesia is various, because Indonesia is an archipelagic country extended from Sabang to Merauke, and there are so many tribes. Those have traditional music such as karawitan, keroncong, gambang kromo as the popular one, and Lampung traditional music which is unwell known. Traditional music is regarded as ethnic music found in Indonesia [1]. Traditional music is born and grows in all Indonesian regions. It has good characteristics, lyrics, and melody used in the language, identity, and music instruments. In the instrument play, each Indonesian tribe has uniqueness to learn.

Lampung Province is in the south part of Sumatra Island. Since 2015, Lampung has had two big cities: Bandar Lampung as the capital city and Kota Metro with 13 regencies consisting of West Lampung, North Lampung, East Lampung, South Lampung, Tulang Bawang, West Tulang Bawang, Tanggamus, Pringsewu, Pesawaran, Mesuji, Way Kanan, and Pesisir Barat [8]. Lampung is popular with a name khua jurai which means two branches of culture: Saibatin or coast or Pepadun Ethnic.

The Lampung traditional music includes talo balak, gamolan pekhing music, or cetik, solo gambus, guitar petting, and so on. Guitar petting is a Lampung traditional music genre with a guitar used to accompany songs as the entertainment or a dance song. For Lampungnese, guitar petting is considered as Lampung classic guitar or solo guitar. This guitar petting is interesting to be researched due to the beauty of its play which is different from the common guitar play; even it is like a gambus play.

During the performance of Lampung guitar petting, the instrument used is not ethnic music born in Indonesian culture. Unlike sampek music from Kalimantan, it uses guitar music. Lampung guitar petting is considered as classic music, and in the Saibatin music, there are two versions of classic music: guitar petting and gambus guitar. Guitar is one of the string music played by picking it using fingers or plectrum. The main part of the guitar is the body and neck with six strings on it [3]. The string is made of nylon or steel wire. In this play, the guitars often used are the acoustic guitar and the classical nylon guitar.

An acoustic guitar is made of wood which has a hollow body. It uses steel wire strings and classic nylon [3]. An acoustic guitar produces a sound made by reflections and vibrations that occur in the sound hole of the guitar itself [7]. The word 'solo' means this guitar can only be played by one person who simultaneously becomes the vocalist. Guitar petting is a genre of traditional Lampung music with a guitar instrument used to accompany songs. It can be said that Lampung guitar petting is an instrument of instrumental vocal music that can be performed in a solo or ensemble format. The custom on stage is the traditional clothes of Saibatin ethnic. People who have never seen the 
performance would think that this play uses a gambus instrument because it is almost similar to it. The Saibatin community is actually more identical to the gambus guitar which is indeed influenced by the ancient Saudi Arabia. The word solo guitar is widely used by the Saibatin tribe because the community considers their classical guitar as gambus [4]. Meanwhile, the Lampungnese, particularly Pepadun ethnic names this play as Lampung's classical guitar. In Lampung society, there are two types of guitar playing, namely guitar playing from the Pepadun and Saibatin ethnics. In the guitar playing, the Saibatin mostly has three themes; they are about bujang gadis (single ladies), life, and bandung sentri. The Bujang gadis theme tells the story of young Lampung teenagers, and theme 'life' tells about a chronology of a person. Bandung sentri contains advice on religion, marriage, and daily life.

The guitar petting played by the Saibatin and Pepadun is very different. This difference makes the traditional music in Lampung so various. In the Alip Mountain area, there are guitar petting players who are very influential in the playing and preservation of Saibatin guitar petting music and had conducted training in Lampung traditional music art at the Bandar Lampung City Learning Studio on 24-30 June 2003. The name of the guitar petting player is Mr. Edi Pulampas who comes from Gunung Alip Tanggamus Regency, and he is very famous for the Saibatin guitar petting performance in Lampung. This study examines how the local wisdom of the Saibatin guitar petting supports the play.

\section{RESEARCH METHOD}

This is qualitative research. Qualitative or "quality" refers to the natural aspect which is often contrasted with quantitative or "quantum" [5]. In addition, qualitative research is a method for exploring and understanding the meaning - by a number of individuals or groups of people ascribed to social or humanitarian problems [2]. Qualitative research or natural research (inquiry) is rooted in the natural setting as wholeness; relies on humans as research tools; has inductive and descriptive data analysis; concerns with the process than the results; sets the focus of the study; and has a temporary research design [5].

According to many experts, ethnography is the work of describing a culture. The main purpose is to understand a life perspective from the point of view of the native population. The essence of ethnography is the effort to pay attention to the meaning of the actions of events that happen to those we want to understand [6]. In addition, ethnography is one of the qualitative research strategies in which the researchers investigate a cultural group in a natural environment for a long period of time in collecting primary data, observation data, and interview data [2]. The researchers employed an ethnographic method approach, because this study describes the behavior of a particular culture, especially the Saibatin Lampung ethnic which has its own characteristics in music playing.

The subject of the research was the Saibatin guitar player who was very well known and competent in the field of Lampung ethnic. The data source can be divided into two, namely primary and secondary data. Primary data source comes from the interviews with ethnic music activists of Lampung guitar petting. Then, it was supported by the secondary data source obtained from observation and documentation. The data were analyzed using a conservative qualitative analysis technique, including data reduction, data presentation, and drawing conclusion. The data were validated through a triangulation technique by reviewing the data from observations, interviews, and documentation.

\section{FINDINGS AND DISCUSSION}

Guitar petting playing is one of the Lampung ethnic music. At first glance, it is similar to gambus playing. However, they are not the same in terms of the tuning and its characteristics. The function of the guitar itself for the Lampung community is as a communication tool between a single man and a woman, because in the past a single lady could not be a guest like today or referred to nganjang gadis. They may meet in the back of the house or kitchen and talk behind a wall. In addition, this music also functions as an entertainment means such as weddings, circumcisions, and gawi custom which are attended by people from various regions. This is a media that is used to express taste, communication, entertainment, and so forth. Guitar petting is played by picking the strings one by one (broken chord) and it has been there for a long time and passed down from generation to generation by Lampungnese. However, for now it is permissible to collaborate with other modern musical instruments such as electric bass, electric guitar, and so on as the entertainment media. A player must have a sense of wiraga, wirama, and wirasa (philosophical values in dance art) in his/her nature This is important because these three aspects will affect the songs sung, so that the Lampung characteristics are not lost. Regarding the Lampung guitar petting presentation format, it can be played by one person who also becomes the vocalist or it can also be performed by two people as the accompanist and singer. In the ancient traditional procession, the position of the guitar player is cross-legged sitting in a traditional house nuwow sesat. However, nowadays this can be played by sitting on a chair with the right leg crossed over the left leg or standing up.

Before playing the guitar in the Lampung guitar petting of Saibatin ethnic, the first thing to do is to get the musical instruments ready such as tuning. Tuning is very important in accompanying the song played to avoid false tones during the play. In addition, the function of tuning is to ease the player in playing the guitar. The tuning of the Saibatin guitar petting used is the standard and original classical tuning. Below is the illustration of the original classical tuning.

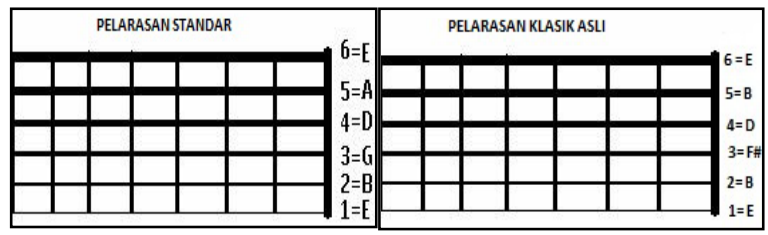

Figure 1 The Tuning of Lampung Guitar Petting by Saibatin (Source: Faizin, 2017) 
Guitar tuning is not stemmed in accordance with the figure above, so tuning may vary according to the ability of a singer to be accompanied. The initial notes on the strings may change but they must have the same interval as the tuning that has been determined. The guitar playing in the Saibatin tribe has its own uniqueness in art. Apart from tuning which is unique in general, the play also uses mode. The mode used is phrgiyan which produces minor nuances like the music in Middle East. Here are the examples of song accompaniment patterns in Lampung guitar petting.

\subsection{Original Classical Tuning}
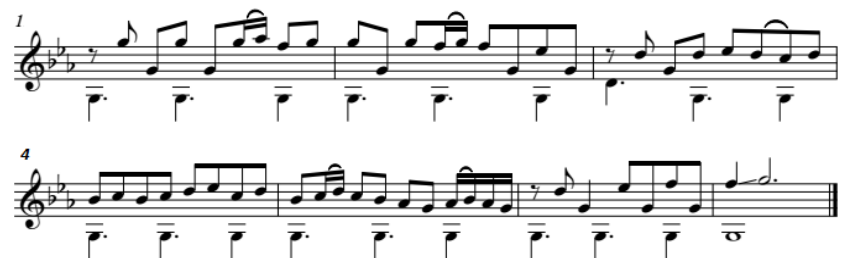

Figure 2 Original Classical Tuning (Transcript: Faizin, June 2017)

The guitar petting accompaniment pattern uses the original classic basic tuning. To play the above notes, String 1 is changed into Note c'; String 2 becomes Note g; String 3 becomes Note d; String 4 becomes Note Bes; String 5 becomes Note G, and String 6 becomes Note C. Most male singers use the E phrygian mode because of the comfort in singing and the vocal power is better in this scale. Whereas, the majority of female vocalists use the $G$ phrygian mode as what is seen in the play above. Since the above notation uses the phrygian mode, the first part starts with Notes g, as, bes, c, d, es, and $\mathrm{f}$. The $\mathrm{G}$ phrygrian mode above produces a major scale at the interval of $(1 / 21$ $\left.11 \frac{1}{2} 11\right)$.

\subsection{Standard Tuning}

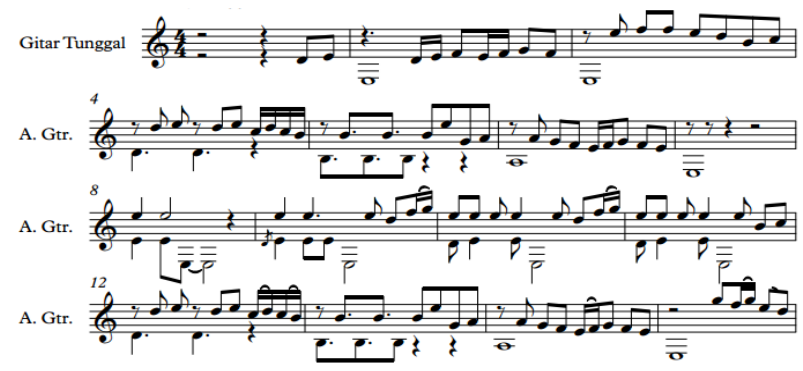

Figure 3 Standard Tuning Partiture (Transcript: Faizin, June 2017)

In standard tuning, the note on the loose string is the same as what we find in the normal guitars. The scale used is the same phrygian mode as that in the original classical tuning.
However, the standard tuning at this time is rarely used, because most players are more likely to play the original classical tuning to follow the market trend so that this tuning is rarely played now. The above tuning is used for religious or advice-themed songs called as bebandung sentri (song of advice) by the Saibatin people. The songs are usually performed at the Lampung traditional wedding procession. The content of the song tells us about religion or advice such as the shahada song written by Lukmansyah. At first glance, this play is similar to a gambus performance.

At this time, there are few Lampung guitar petting players or even none. This guitar petting accompaniment uses improvisation, so that a player can variously pick the guitar. They only refer to the chords contained in the song. In short, the patterns of the strum and rhythm are in accordance with what is desired by the accompanist through the player's own appreciation.

The guitar petting players use an intro to give a signal, so that the vocalist or singer can understand when to start the theme of the song. It uses the phrygian mode and only three types of chords namely iii, v, and vi. They do not use other chords besides these three. The majority of the bass use tonics from the phrygian mode. The song intro is used to give a signal for the vocalist or singer, so he/she knows when to enter the main theme of the song. This playing also has unique Malay characteristics.

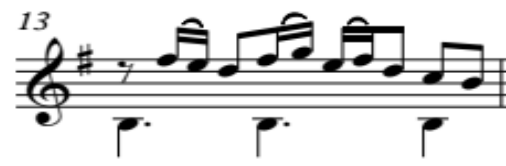

Figure 4 Original Classical Tuning (Transcript: Faizin, June 2017)

This section is a distinctive feature of the Saibatin guitar playing in musical accompaniment where it uses descending slur and ascending slur techniques. The typical minor nuances of Lampung can be illustrated by the partiture above. The songs in the playing are fairly calm, because Lampung is still a Malay ethnic with very distinctive vocal twists.

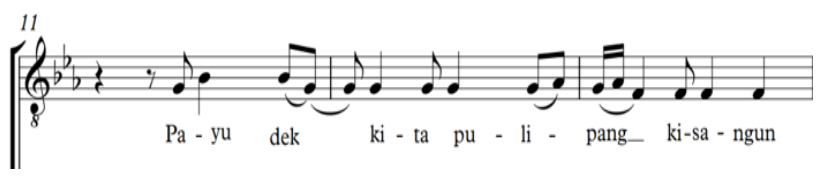

Figure 5 Original Classical Tuning (Transcript: Faizin, June 2017)

In the partiture, the twist can be seen in the word "Pulipang" through very unique notation tones of the Malay ethnic community in Lampung. Unique twist in Malay is delivered by means of a word fragment of with 
more than three notes (legato). The most important thing in performing Lampung guitar petting accompaniment is the improvisation skills of the players themselves. Each player can have a different accompaniment, but it is also undeniable that there is a player known as a duplicate. A duplicate player mimics in such a way other people's performance. To accompany the song, they use the slimpat rhythm. This rhythm is almost the same as the dangdut pattern.

\section{CONCLUSION}

The function of guitar for Lampungnese is as a communication means between a single man and a woman, because in the past a single person could not come as a guest like today, it is referred to as nganjang gadis. This playing is a media used to express taste, communication, and entertainment. Guitar playing is played by picking strings one by one or broken chord, and it has been existing for a long time and passed down from generation to generation by Lampungnese. A player must have a sense of wiraga, wirama, and wirasa in his nature. The Lampung guitar petting performance format can be played by one person as the guitar player as well as a singer or two people with one accompanist and one singer. During the traditional procession in the past, the position used was to sit cross-legged in the traditional house nuwo sesat. However, this can be played by sitting on a chair with the right leg crossed over the left one or standing up.

The Saibatin guitar petting uses the standard and original classical tuning. Guitar tuning does not have to be stemmed in accordance with the above tuning. Apart from tuning which is different in general, this play also uses a phrgiyan mode producing minor nuances like the music in Middle East. The tones in the phrygian mode are g, as, bes, $\mathrm{c}$, d, es, and f. This petting guitar accompaniment uses improvisation, so that a player can variously strum the guitar. They only refer to the chords contained in the song; the chords used are iii, $\mathrm{v}$, and vi.

The Saibatin guitar petting uses the descending slur and ascending slur techniques to raise the typical Malay characteristics. Unique twist in Malay is delivered by means of a word fragment with more than three notes (legato). The most important thing in performing the Lampung guitar petting accompaniment is the improvisation skills of the players themselves. To accompany the song, they use the slimpat rhythm, which is almost the same as the dangdut pattern.

\section{REFERENCES}

[1] Artistiana, N.Rilla. "Aneka Alat Musik Daerah [Various Regional Musical Instruments]." Jakarta: Horizon (2010).

[2] Creswell, John W. "Research Design: pendekatan metode kualitatif, kuantitatif, dan campuran [Research Design: Qualitative, Quantitative, and Mixed Methods Approaches]." Yogyakarta: Pustaka Pelajar (2016).

[3] Misthohizzaman. Gitar Klasik Lampung, Musik dan Identitas Masyarakat Tulang Bawang [Lampung Classical Guitar, Music and Community Identity of Tulang Bawang]. Thesis. UGM, 2006. http://etd.repository.ugm.ac.id/home/detail_pencarian/3 0390

[4] Mistortoify, Zulkarnain. Fieldwork I Etnomusikologi. Surakarta: P2AI bekerjasama dengan STSI PREES Surakarta, 2003.

[5] Spradley, James P. "Metode Etnografi [Ethnographic Method]." Yogyakarta: PT." Tiara Wacana 5 (1997).

[6] Solapung, Kaye A. Gitar Tunggal [A Solo Guitar] . Cet ke-4. Jakarta: PT Indira (1983).

[7] Tim Penyusun. Lampung Dalam Angka [Lampung in Numbers]. Lampung: Badan Pusat Statistik Provinsi Lampung, 2015. 